\title{
Studi Eksperimental tentang Karakteristik Airfoil Naca 0015 Berskat Bagian atas dengan Variasi Jarak Skat
}

\author{
Setyo Hariyadi S.P. ${ }^{1,2}$, Didit Waskito ${ }^{1}$ \\ 1) Laboratorium Mekanika dan Mesin Fluida \\ Jurusan Teknik Mesin, Fakultas Teknologi Industri, Institut Teknologi Sepuluh \\ Nopember (ITS) \\ J1. Arief Rahman Hakim, Surabaya 60111 Indonesia \\ 2) Program Studi Teknik Pesawat Udara, Politeknik Penerbangan Surabaya \\ Jl. Jemur Andayani I/73, Wonocolo, Surabaya 60236 \\ Email: hudzaifahsetyo@gmail.com
}

\begin{abstract}
Abstrak
Gaya lift merupakan salah satu gaya yang bekerja pada benda jika terdapat perbedaan distribusi tekanan antara sisi atas dengan sisi bawah bilamana aliran fluida melewatinya. Dalam perancangan sayap pesawat terbang, gaya aerodinamik (gaya lift dan $d r a g$ ) merupakan parameter yang penting. Oleh sebab itu usaha-usaha dan penelitian untuk meningkatkan kinerja sayap, banyak yang dilakukan orang.

Dalam penelitian yang dilakukan ini, dikaji pengaruh dari pemberian skat-skat pada sayap pesawat terbang NACA 0015 simetri, terhadap kinerja sayap, dengan mengukur gaya lift $\left(F_{L}\right)$ dan gaya drag $\left(F_{D}\right)$ yang ditunjang data $C_{P}$ dan dilakukan secara eksperimental pada terowongan angin subsonic.

Studi eksperimental yang dilakukan di wind tunnel untuk model airfoil NACA 0015 terbukti bahwa penambahan skat pada bagian atas mampu meningkatkan lift.

Kata kunci: Skat, lift, drag dan Koeffisien tekanan

\section{PENDAHULUAN}

Semenjak Otto "The Glinder man" Lilienthal (1896) dan Wright Brother dapat menerbangkan "The Flyer I" selama 59 detik (1903) hingga kini perkembangan pesawat terbang semakin pesat. Perkembangan tersebut juga diimbangi dengan perkembangan material yang lebih ringan dan cara perancangan yang lebih optimum, terutama pada sayap pesawat terbang.

Pesawat terbang mampu mengangkat beban yang cukup berat karena adanya gaya angkat yang dibangkitkan sendiri oleh sayap pesawat terbang tersebut. Gaya angkat yang terjadi disebabkan oleh perbedaan tekanan pada permukaan atas dan permukaan bawah dari sayap. Apabila suatu sayap pesawat menembus suatu medan aliran bebas dengan pemberian sudut serang tertentu maka akan timbul perbedaan tekanan serta kecepatan antara profil yang atas dengan profil yang bawah pada sayap pesawat. Pada sisi atas sayap terjadi peningkatan kecepatan namun akan mengalami penurunan tekanan statis dan akan diimbangi dengan kenaikan tekanan dinamisnya. Dengan adanya perbedaan tekanan tersebut maka sayap pesawat akan terdorong naik ke atas dan gaya untuk menaikkan kinerja sayap pesawat ini disebut lift force.

Salah satu cara untuk menaikkan kinerja sayap pesawat ini adalah dengan penambahan kecepatan pada bagian atas sayap tersebut, sehingga didapatkan peningkatan momentum aliran pada sisi atas sayap pesawat. Hal ini dapat memundurkan titik separasi serta dapat memperkecil daerah wake dan pada akhirnya akan meningkatkan lift force (gaya angkat). Penambahan kecepatan ini diduga dapat dilakukan dengan cara memberikan skat-skat pada bagian atas pesawat. Peningkatan kinerja sayap pesawat terbang dapat dilakukan dengan mengaktifkan boundary layer control dengan cara menambahkan momentum aliran udara pada dinding sayap melalui penyekatan aliran udara pada bagian atas.
\end{abstract}




\section{METODOLOGI}

Peralatan utama selain model sayap (airfoil) adalah terowongan angin. Percobaan melalui terowongan angin ini dimaksudkan agar sayap dapat diuji dalam skala model. Pengujian sayap pada pengukuran sebenarnya cukup sulit, lagi pula memerlukan biaya yang besar. Tetapi sudah barang tentu kondisi-kondisi pada saat pengujian diusahakan mendekati kenyataan. Terowongan angin yang digunakan adalah jenis open circuit wind tunnel, yaitu jenis wind tunnel dimana udara yang dialirkan, tidaknya dapat disirkulasikan, tetapi langsung dilepas ke udara bebas setelah melalui test section. Menurut kecepatan dari udaranya, wind tunnel ini tergolong subsonic wind tunnel, yaitu jenis terowongan angin yang mempunyai kecepatan aliran udara dibawah 0.9 mach. Terowongan angin yang digunakan dalam percobaan ini adalah jenis open circuit low speed wind tunnel yang ditampilkan pada gambar 1. Data teknis yang dimiliki terowongan angin ini adalah:

- Jenis

- Catu daya listrik

: Subsonic open circuit wind tunnel

- Dimensi utama

: 240 volt $/ 50 \mathrm{~Hz}, 1.5 \mathrm{KW}$

- Working section

: $2980 \times 1830 \times 800 \mathrm{~mm}$

- Kec. Alir udara maksimum

: $300 \mathrm{~mm}$ (octagonal) x 450 (panjang)

- Lift balans maksimum

$: 25 \mathrm{~m} / \mathrm{s}$

- Drag balans maksimum

$: 7.0 \mathrm{~N}$

- Sensitivitas maksimum

$: 2.5 \mathrm{~N}$

$: 0.01 \mathrm{~N}$

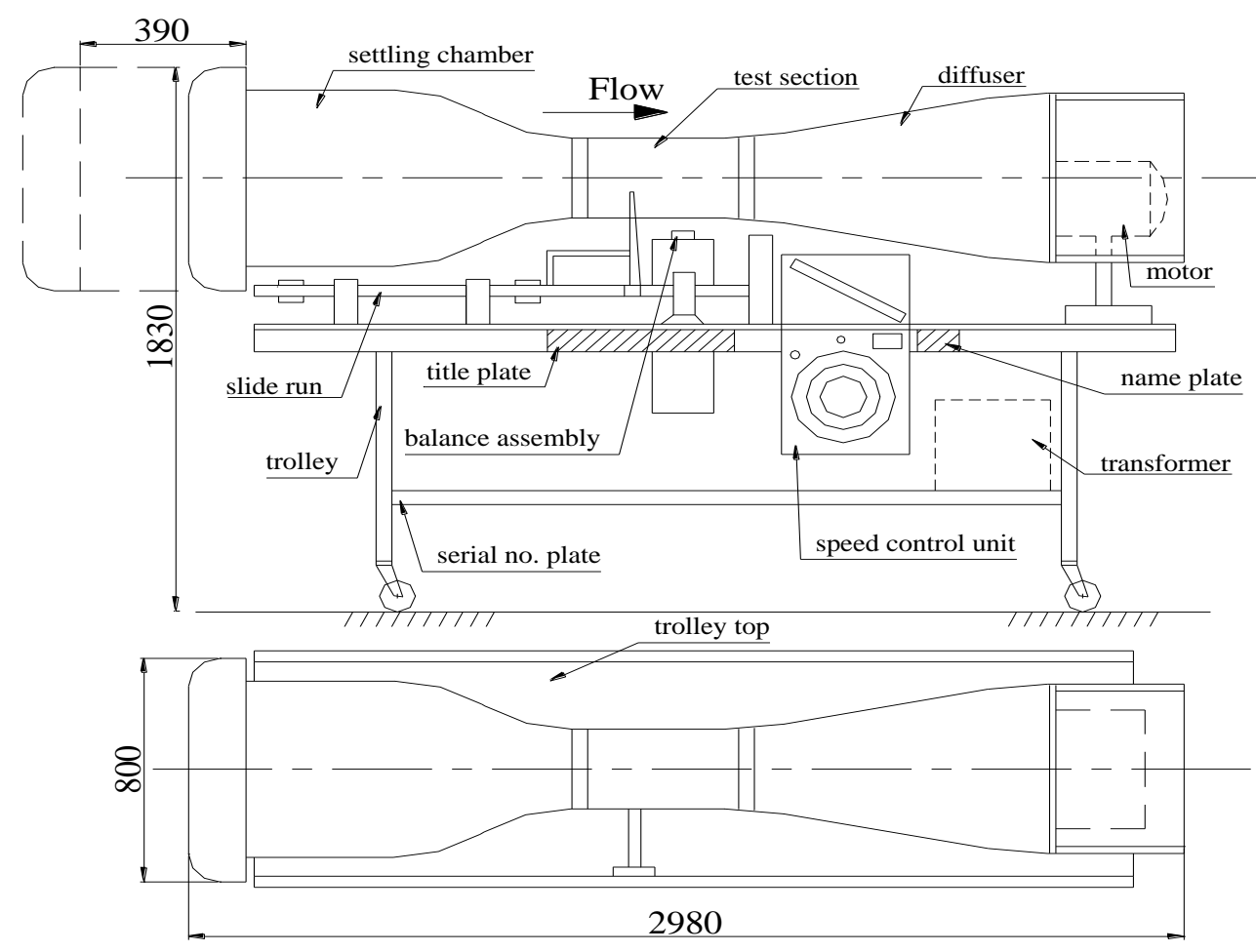

Gambar 1. Subsonic wind tunnel

Model sayap yang digunakan dalam percobaan ini adalah sayap simetris NACA 0015 dengan modifikasi penambahan skat pada bagian atas untuk mengerahui pengaruh penyekatan aliran terhadap penambahan lift dan $d r a g$ ditunjang distribusi tekanan pada sayap tipe NACA 0015 sebagaimana terlihat pada gambar 2 . 

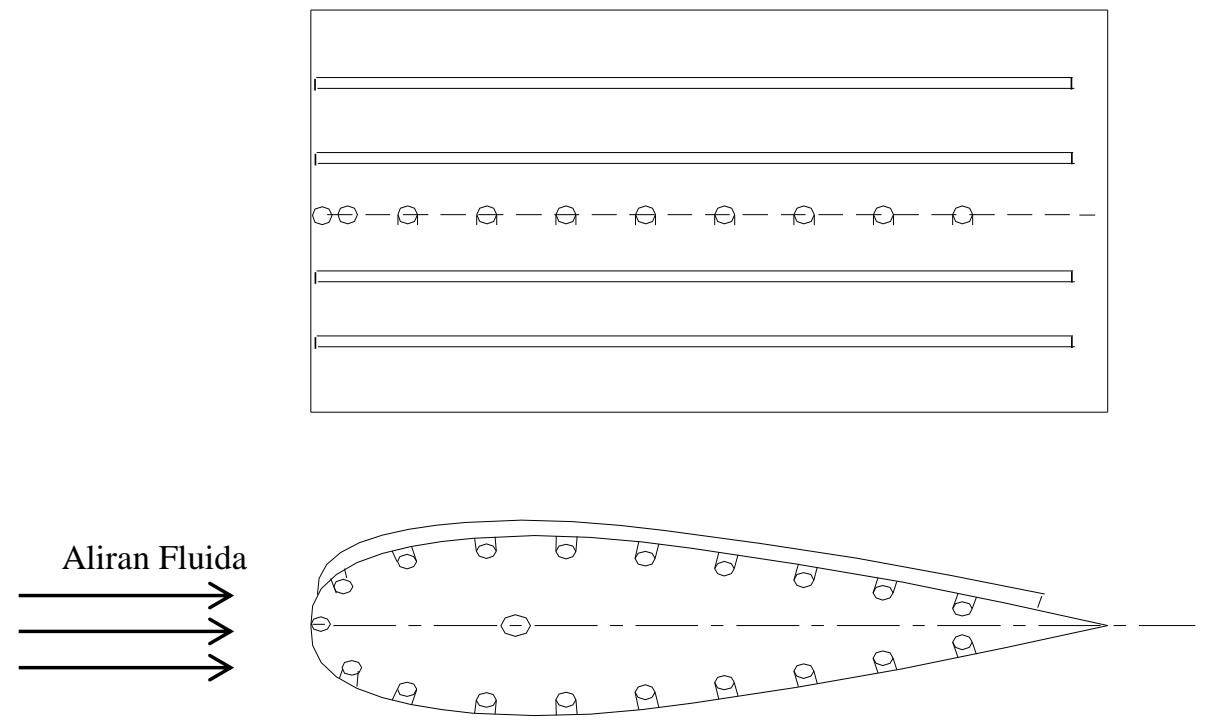

Gambar 2. Profil dengan peambahan skat

Skat yang digunakan adalah mika dengan tinggi $20 \mathrm{~mm}$ dan tebal $2 \mathrm{~mm}$.yang berguna untuk mengarahkan aliran sehingga terjadi percepatan aliran. Penyekatan yang dilakukan ada tiga tahap yaitu dengan jarak skat $20 \mathrm{~mm}, 25 \mathrm{~mm}$ dan $30 \mathrm{~mm}$.hal ini dimaksudkan untuk mengetahui pengaruh pemasangan skat dan jarak skat dengan ditunjang data $C_{P}$.

Aliran yang digunakan dalam percobaan ini adalah $15 \mathrm{~m} / \mathrm{s}\left(R e=2,27 \times 10^{6}\right)$ dimana kecepatan tersebut digunakan pada model sayap tanpa skat dan menggunakan skat dengan variasi jarak skat.

\section{HASIL DAN PEMBAHASAN}

\section{Analisa perubahan $C_{D}$ dan $C_{L}$}

\section{Pengaruh penggunaan skat terhadap gaya seret.}

Penambahan momentum kedalam boundary layer pada hakekatnya untuk melawan gaya gesek dari dinding kontur, sehingga memperbaiki struktur dari boundary layer. Perbaikan ini selanjutnya dapat berpengaruh terhadap gaya seret dan angkat. Gambar 3 memperlihatkan grafik koeffisien drag fungsi sudut serang untuk kondisi tanpa skat dan menggunakan skat dengan 3 variasi jarak yang disajikan dalam perbandingan jarak terhadap tinggi skat $(\mathrm{t} / \mathrm{h})$.

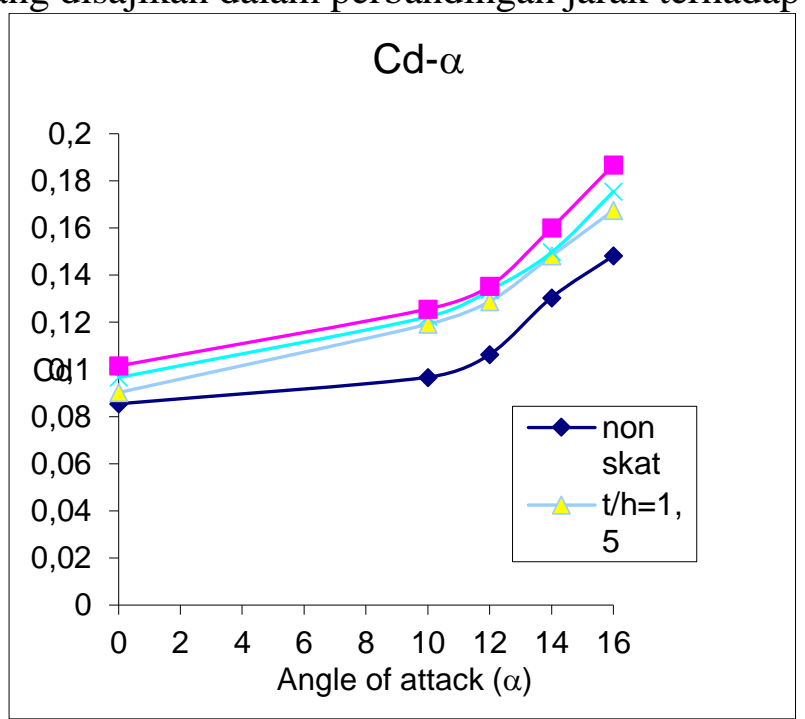

Gambar 3. Grafik perubahan $C_{D}$ terhadap sudut serang 
Gambar 3 menjelaskan bahwa dengan penggunaan skat tampak terjadi peningkatan $C_{D}$ dibandingkan tanpa menggunakan skat. Secara umum hal ini disebabkan oleh bertambahmya bidang gesek akibat adanya skat. Peningkatan $C_{D}$ terbesar terjadi pada $\mathrm{t} / \mathrm{h}=1$ dan peningkatan $C_{D}$ terkecil pada $\mathrm{t} / \mathrm{h}=1,5$. Hal ini dimungkinkan karena pada $\mathrm{t} / \mathrm{h}=1$, ruangan yang membatasi aliran terlalu sempit sehingga Aliran fluida yang memasuki lorong skat terkontraksi akibat kondisi masukan dan gaya gesek pada permukaan dinding-dinding skat (fenomena aliran 3D). Sehingga momentum aliran akan cenderung tidak lebih mampu menahan gesekan dan tekanan balik yang terjadi, akibatnya memungkinkan mempercepat terjadinya titik separasi. Hal ini yang menyebabkan $d r a g$ yang ditimbulkan pada $\mathrm{t} / \mathrm{h}=1$ lebih besar. Pernyataan di atas akan diperkuat dengan hasil pengukuran distribusi $C_{P}$ sepanjang cord.

$>$ Pengaruh penggunaan skat terhadap gaya angkat

Pengaruh penggunaan skat terhadap gaya angkat dapat dianalisa dari gambar grafik 4 . di bawah yang menampilkan grafik koeffisien gaya angkat $\left(C_{L}\right)$ fungsi sudut serang $(\alpha)$. Gambar tersebut menjelaskan bahwa dengan penambahan skat meningkat pula gaya angkat yang terjadi bila dibandingkan dengan tanpa penambahan skat. Hal ini dimungkinkan karena karena dengan penambahan skat maka terjadi akselerasi aliran melalui lorong-lorong antara skat-skat tersebut, maka aliran pada permukaan atas lebih mampu melawan gaya gesek dari permukaan airfoil. Sedangkan pada permukaan bawah dalam kondisi tetap sehingga terjadi penambahan perbedaan tekanan antara permukaan atas dengan permukaan bawah, dan akibatnya lift menjadi meningkat.

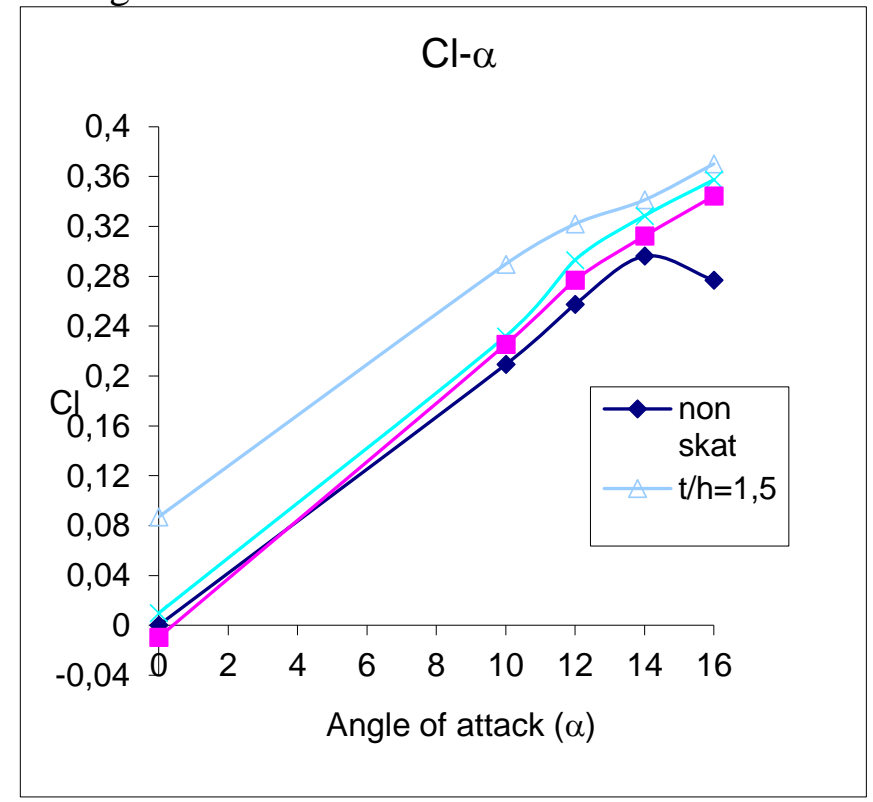

Gambar 4. Grafik perubahan $C_{L}$ terhadap sudut serang

Kenaikan $C_{L}$ terbesar terjadi pada $\mathrm{t} / \mathrm{h}=1,5$ karena jaraknya cukup lebar sehingga dimungkinkan pada jarak ini Aliran yang terkontraksi karena kondisi masukan mempunyai pengaruh yang kecil terhadap keseluruhan aliran fluida yang memasuki lorong-lorong skat. Akibatnya aliran udara menjadi lebih cepat dan tekanan permukaan atas cenderung lebih rendah sehingga menghasilkan lift yang lebih besar dibandingkan jarak skat yang lebih sempit $(\mathrm{t} / \mathrm{h}=1$ dan $\mathrm{t} / \mathrm{h}=1,25)$.

Sedangkan untuk kenaikan $C_{L}$ yang terkecil terjadi pada $\mathrm{t} / \mathrm{h}=1$, karena jarak skat terlalu sempit sehingga walaupun ada akselerasi aliran karena penyekatan tetapi Aliran yang terkontraksi pada kondisi masukan antar skat cukup besar pengaruhnya untuk menahan sebagian aliran yang memasuki lorong-lorong skat. sehingga kenaikan lift yang diharapkan dari akselerasi tersebut berkurang (tidak maksimal). Selain itu dengan penambahan skat tersebut tampaknya juga membuat stall terjadi pada sudut serang $(\alpha)$ yang lebih tinggi. 
$>$ Pengaruh penggunaan skat terhadap $C_{L} / C_{D}$

Pengaruh penggunaan skat terhadap perbadingan peningkatan gaya angkat dan gaya seret dapat dianalisa dari gambar 5, yang mana menampilkan grafik perbandingan koeffisien lift dengan koeffisien drag $\left(C_{L} / C_{D}\right)$ terhadap sudut serang. Gambar tersebut menjelaskan bahwa dengan dengan penambahan skat maka ada peningkatan $C_{L} / C_{D}$ pada $\mathrm{t} / \mathrm{h}=1,5$ sedangkan untuk $\mathrm{t} / \mathrm{h}=1$ dan $\mathrm{t} / \mathrm{h}=1,25 C_{L} / C_{D}$ turun.

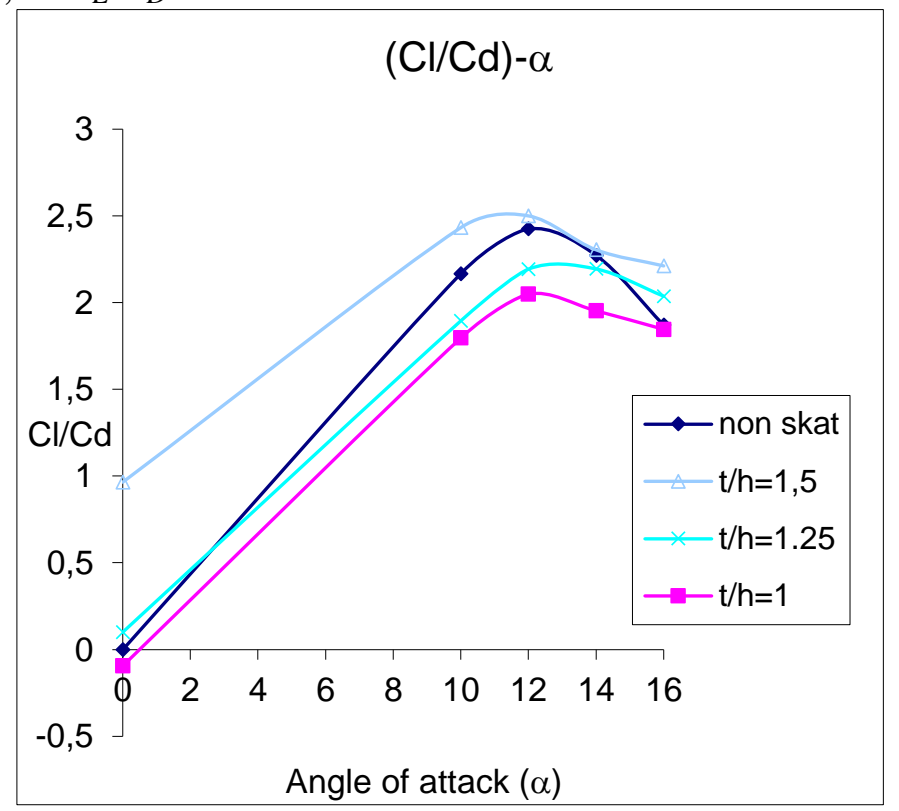

Gambar 5. grafik perubahan $C_{L} / C_{D}$ terhadap sudut serang

Dari grafik tersebut tampak bahwa penambahan skat pada $\mathrm{t} / \mathrm{h}=1,5$ sangat efektif untuk menaikkan kinerja sayap tetapi untuk jarak lebih kecil $(\mathrm{t} / \mathrm{h}=1$ dan $\mathrm{t} / \mathrm{h}=1,25)$ justru dapat menurunkan kinerja sayap. Dimana untuk memperbaiki kinerja sayap kita harus memaksimalkan lift yang dihasilkan dan meminimalkan drag yang ditimbulkan dari kenaikan lift tersebut. Pada $\mathrm{t} / \mathrm{h}=1$ dan $\mathrm{t} / \mathrm{h}=1,25$ kenaikan lift diiringi dengan kenaikan drag yang perbandingan lift dengan dragnya turun jika dibandingkan dengan tanpa skat. Tetapi untuk $\mathrm{t} / \mathrm{h}=1,5$ perbandingan lift dan dragnya naik dibandingkan dengan tanpa skat sehingga bisa dikatakan penambahan skat pada $\mathrm{t} / \mathrm{h}=1,5$ dapat meningkatkan kinerja sayap. Hal ini dimungkinkan karena pada jarak skat yang terlalu sempit Aliran yang terkontraksi pada kondisi masukan dan gaya gesek di pemukaan dinding-dinding skat besar pengaruhnya untuk menahan sebagian aliran yang memasuki lorong-lorong skat, sehingga dapat menaikkan drag dan lift yang dihasilkan tidak dapat maksimal. Sedangkan untuk $\mathrm{t} / \mathrm{h}=1,5$ jaraknya cukup lebar sehingga pengaruh aliran terkontrakasi pada kondisi masukan antar skat cukup kecil terhadap keseluruhan aliran yang memasuki lorong-lorong skat. Dengan demikian kenaikan drag yang disebabkan gaya gesek dari dinding skat kecil dan lift yang dihasilkan bertambah besar.

\section{Analisa terhadap Perubahan nilai $C_{P}$}

Dari data percobaan yang diolah dalam lampiran yang kemudian ditampilkan dalam grafik koeffisien tekanan fungsi $\mathrm{x} / \mathrm{c}$ seperti pada beberapa gambar pada analisa berikut.

Perubahan nilai $C_{\boldsymbol{P}}$ pada $\alpha=\mathbf{0}^{0}$

Perubahan $C_{P}$ tanpa skat

Pada gambar tampak sebelum menggunakan skat titik separasi terjadi di sekitar $60 \%$ Chord. baik di permukaan atas maupun permukaan bawah. Tekanan minimum terjadi di sekitar 26\% Chord. Kemudian bergerak ke belakang aliran mengalami penurunan kecepatan. Tetapi aliran masih mampu mengatasi gaya gesek da6 ri permukaan. Sedangkan 
pada daerah sekitar 60\% Chord aliran mulai terseparasi dimana hal ini ditandai harga $C_{P}$ yang mulai konstan. Hal ini terjadi karena gaya gesek dan adverse pressure gradient semakin besar sehingga momentum yang ada tidak mampu lagi mengatasinya. Karena pada permukaan bawah dan atas Gradien tekanannya relatif hampir sama serta separasi terjadi di jarak x/c yang sama sekitar $60 \%$ chord, maka tidak ada perbedaan tekanan antara sisi atas dan sisi bawah yang mampu menghasilkan lift.

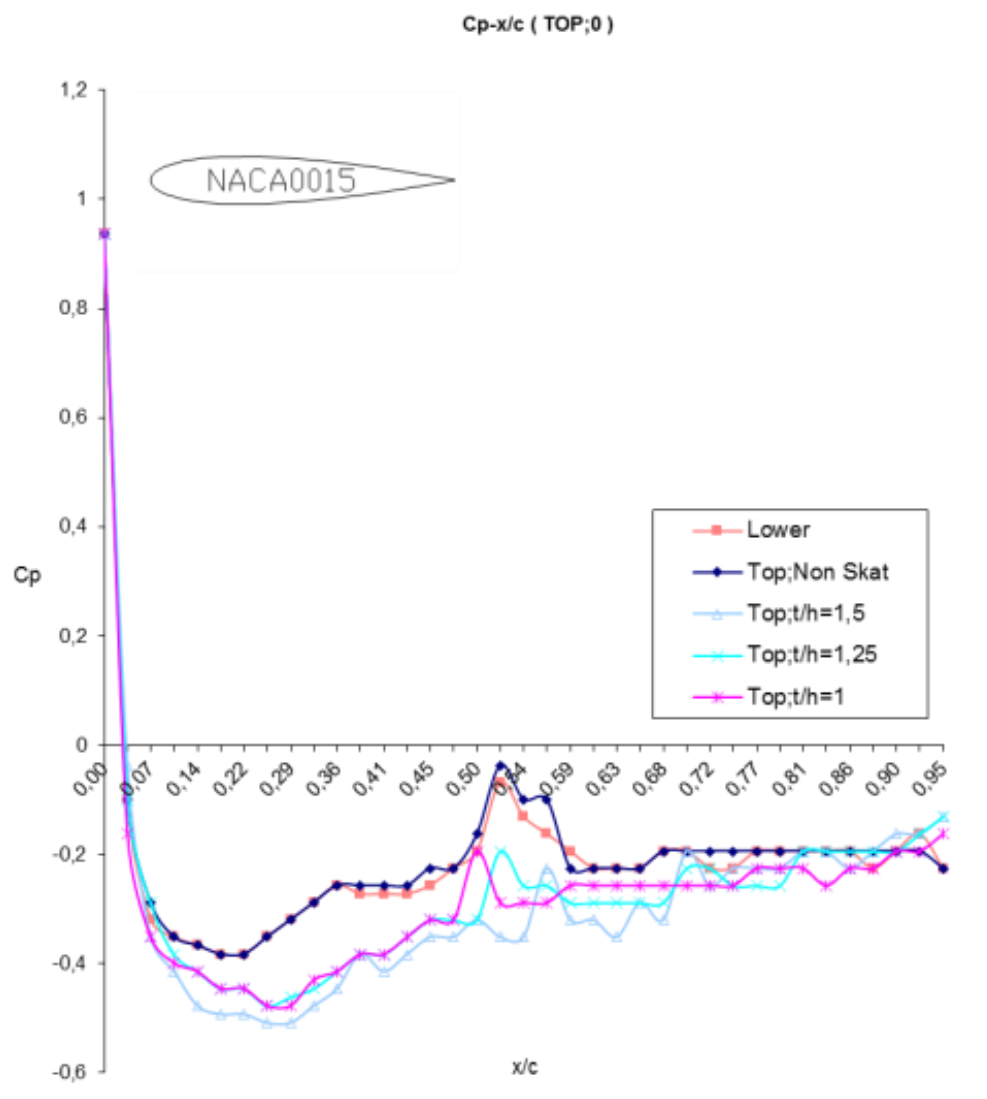

Gambar 6. Perubahan nilai $C_{P}$ terhadap x/c $\left(\alpha=0^{0}\right)$

Perubahan $C_{P}$ dengan penambahan skat bagian atas

Dengan penambahan skat pada bagian atas ternyata membuat tekanan minimum di permukaan atas semakin turun kebawah dan mundur disekitar 33\% chord, ini menunjukkan adanya penambahan akselerasi aliran dengan penambahan skat. Sedangkan pada permukaan bawah relatif tidak berubah. Tetapi pada $\mathrm{t} / \mathrm{h}=1$ ini titik separasi terjadi lebih awal dibandingkan dengan tanpa skat. Hal ini dimungkinkan karena jarak skat terlalu sempit sehingga Aliran yang terkontraksi pada kondisi masukan antar skat sangat besar pengaruhnya untuk menahan sebagian aliran fluida yang memasuki lorong-lorong skat.

Sedangkan untuk $\mathrm{t} / \mathrm{h}=1,25$ dan $\mathrm{t} / \mathrm{h}=1,5$ tampak adanya akselerasi sehingga terjadi penurunan titik koeffisien minimum dan kemunduran titik separasi. Ini menunjukkan momentum aliran yang ditambahkan dari penyekatan lebih mampu melawan gaya gesek dari permukaan kontur. Dari kejadian itu maka timbullah gaya angkat yang disebabkan perbedaan tekanan antara sisi atas dengan sisi bawah airfoil. Hal ini sekaligus memperkuat hasil pengukuran $C_{D}$ dan $C_{L}$. 


\section{Perubahan nilai $C_{P}$ pada $\alpha=\mathbf{1 0}^{0}$}

Perubahan $C_{P}$ tanpa skat

Pada gambar 7 tampak sebelum menggunakan skat titik separasi terjadi di sekitar 54\% Chord, pada permukaan atas sedangkan pada permukaan bawah aliran diperlambat pada awal masuk sisi bawah airfoil sehingga tekanannya naik lalu aliran kembali dipercepat tetapi titik koeffisien tekanan minimum masih diatas koeffisien tekanan minimum sisi atas sehingga terjadilah perbedaan tekanan sisi atas dan sisi bawah yang bisa menghasilkan lift.

Pada permukaan bagian atas titik koeffisien tekanan minimum terjadi disekitar 9\% chord, Kemudian bergerak ke belakang aliran mengalami penurunan kecepatan. Tetapi aliran masih mampu mengatasi gaya gesek dari permukaan. Hingga pada daerah sekitar 54\% Chord aliran mulai terseparasi dimana hal ini ditandai dengan harga $C_{P}$ yang mulai relatif konstan, yang berarti momentum yang ada sudah tidak mampu lagi mengatasi gaya gesek dan adverse pressure gradient yang semakin besar.

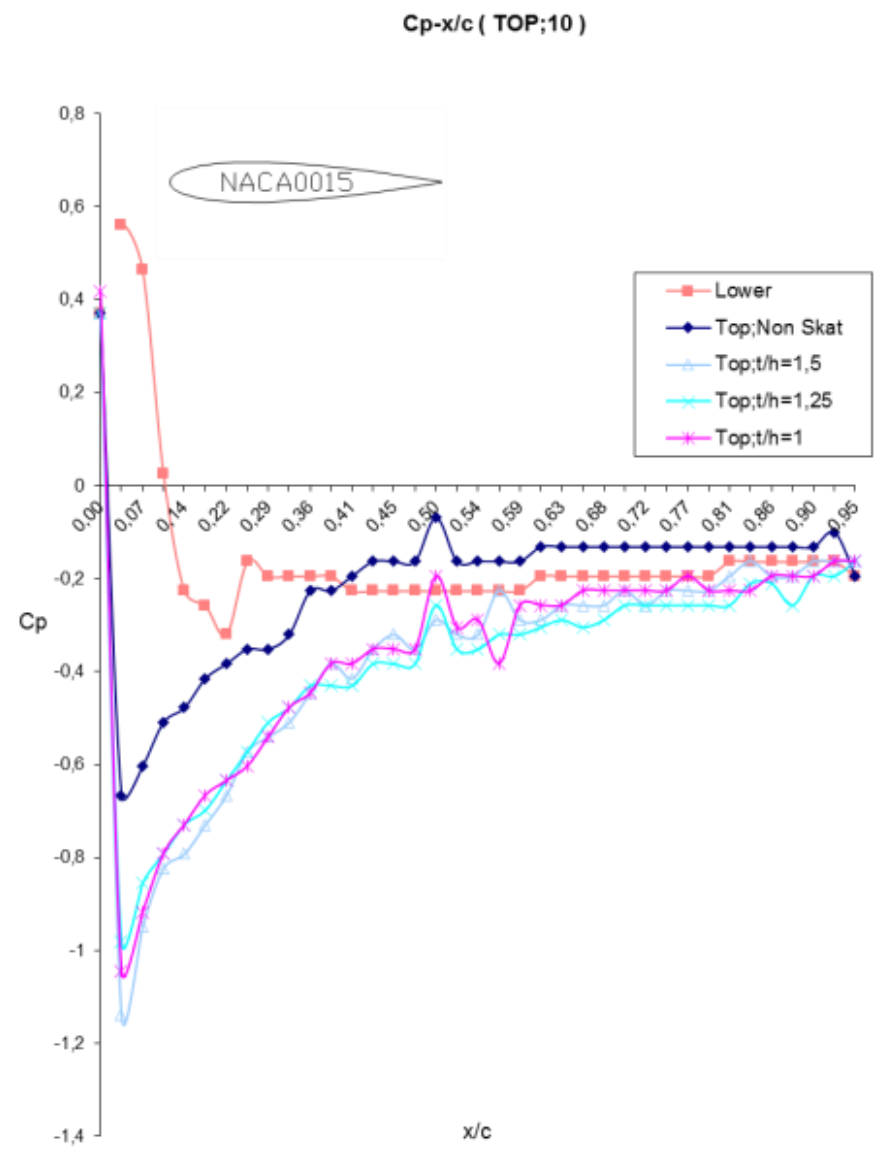

Gambar 7. Perubahan nilai $C_{P}$ terhadap x/c $\left(\alpha=10^{0}\right)$

Perubahan $C_{P}$ dengan penambahan skat bagian atas

Dengan penambahan skat pada bagian atas ternyata membuat tekanan minimum di permukaan atas semakin turun kebawah. Sedangkan pada permukaan bawah relatif tidak berubah. Pada $\mathrm{t} / \mathrm{h}=1$ ini titik separasi terjadi di daerah jarak chord yang hampir sama dengan tanpa skat tetapi dengan tekanan yang lebih kecil. Sehingga disinilah terjadi peningkatan lift dibanding dengan tanpa skat.

Untuk $\mathrm{t} / \mathrm{h}=1,25$ titik koeffisien tekanan minimum lebih kebawah sehingga tekanan minimum yang dihasilkan lebih kecil dibanding dengan tanpa skat. Jika dibandingkan dengan $\mathrm{t} / \mathrm{h}=1$ tekanan minimumnya lebih tinggi tetapi pressure gradiennya lebih landai 
sehingga bisa dikatakan lebih sedikit kehilangan kecepatan yang disebabkan kontraksi aliran pada kondisi masukan antar skat dan gaya gesek pada dinding-dinding skat. Sedangkan pada permukaan bawah relatif tidak berubah. Pada $\mathrm{t} / \mathrm{h}=1.25$ titik separasi terjadi di daerah jarak chord yang hampir sama dengan tanpa skat dan $\mathrm{t} / \mathrm{h}=1$ tetapi dengan tekanan yang lebih kecil. Sehingga disinilah terjadi peningkatan lift dibanding dengan keduanya.

Untuk $\mathrm{t} / \mathrm{h}=1,5$ titik koeffisien tekanan minimum lebih kebawah lagi sehingga tekanan minimum yang dihasilkan lebih kecil dibanding dengan tanpa skat, $\mathrm{t} / \mathrm{h}=1$ dan $\mathrm{t} / \mathrm{h}=1,25$. Pada $\mathrm{t} / \mathrm{h}=1,5$ titik separasi terjadi di daerah jarak chord yang lebih mundur dibanding dengan tanpa skat, $\mathrm{t} / \mathrm{h}=1$ dan $\mathrm{t} / \mathrm{h}=1,25$. Sehingga disinilah terjadi perbedaan tekanan terbesar antara sisi atas dengan sisi bawah airfoil yang bisa menghasilkan lift paling besar. Hal ini sekaligus juga memperkuat hasil pengukuran $C_{D}$ dan $C_{L}$.

\section{Perubahan nilai $C_{P}$ pada $\alpha=12^{0}$}

$>$ Perubahan $C_{P}$ tanpa skat

Pada gambar 8 tampak sebelum menggunakan skat titik separasi terjadi di sekitar 52\% Chord, pada permukaan atas sedangkan pada permukaan bawah aliran diperlambat pada awal masuk sisi bawah airfoil sehingga tekanannya naik dan disekitar 9\% chord aliran kembali dipercepat tetapi titik koeffisien tekanan minimum masih diatas koeffisien tekanan minimum sisi atas sehingga terjadilah perbedaan tekanan sisi atas dan sisi bawah yang bisa menghasilkan lift. Lift yang dihasilkan lebih besar dibandingkan sudut serang $0^{0}$ dan $10^{\circ}$, hal ini dikarenakan titik koeffisien minimum sisi atas lebih ke bawah yang berarti tekanan pada permukaan atas lebih kecil.

Pada permukaan bagian atas titik koeffisien tekanan minimum terjadi disekitar 9\% chord, Kemudian bergerak ke belakang aliran mengalami penurunan kecepatan. Tetapi aliran masih mampu mengatasi gaya gesek dari permukaan yang ditambah gradien tekanan yang positif. Tetapi pada daerah sekitar 52\% Chord aliran mulai terseparasi dimana hal ini ditandai dengan harga $C_{P}$ yang cenderung mulai konstan. Hal ini berarti momentum yang ada sudah tidak mampu lagi mengatasi gaya gesek dan adverse pressure gradient yang semakin besar.

Perubahan $C_{P}$ dengan penambahan skat bagian atas.

Dengan penambahan skat pada bagian atas ternyata membuat tekanan minimum di permukaan atas semakin turun kebawah ini menunjukkan adanya akselerasi aliran dengan adanya penambahan skat. Sedangkan pada permukaan bawah relatif tidak berubah. Pada $\mathrm{t} / \mathrm{h}=1$ titik separasi terjadi sediki mundur ke belakang dibandingkan dengan tanpa skat tetapi dengan tekanan yang lebih kecil.

Untuk $\mathrm{t} / \mathrm{h}=1,25$ titik koeffisien tekanan minimum lebih kebawah sehingga tekanan minimum yang dihasilkan lebih kecil dibanding dengan tanpa skat. Jika dibandingkan dengan $t / h=1$ tekanan minimumnya lebih tinggi tetapi pressure gradiennya lebih landai sehingga bisa dikatakan lebih sedikit kehilangan kecepatan yang disebabkan kontraksi aliran pada kondisi masukan antar skat dan gaya gesek pada dinding-dinding skat. Sedangkan pada permukaan bawah relatif tidak berubah.

Untuk $\mathrm{t} / \mathrm{h}=1,5$ titik koeffisien tekanan minimum yang terjadi hampir sama dengan $\mathrm{t} / \mathrm{h}=1$. tetapi pressure gradiennya lebih landai sehingga bisa dikatakan lebih sedikit kehilangan kecepatan yang disebabkan kontraksi aliran pada kondisi masukan antar skat dan gaya gesek pada dinding-dinding skat. Sedangkan pada permukaan bawah relatif tidak berubah. Pada $\mathrm{t} / \mathrm{h}=1,5$ titik separasi terjadi di daerah jarak chord yang lebih mundur.

Dari grafik diatas tampak dengan penambahan skat terjadi penurunan koeffisien tekanan minimum ini berarti ada akselerasi aliran sehingga momentum aliran yang menyebabkan perbedaan tekanan sisi atas dengan sisi bawah semakin besar sehingga lift 
yang dihasilkan semakin besar pula. Hal ini juga untuk memperkuat hasil pengukuran $C_{D}$ dan $C_{L}$.

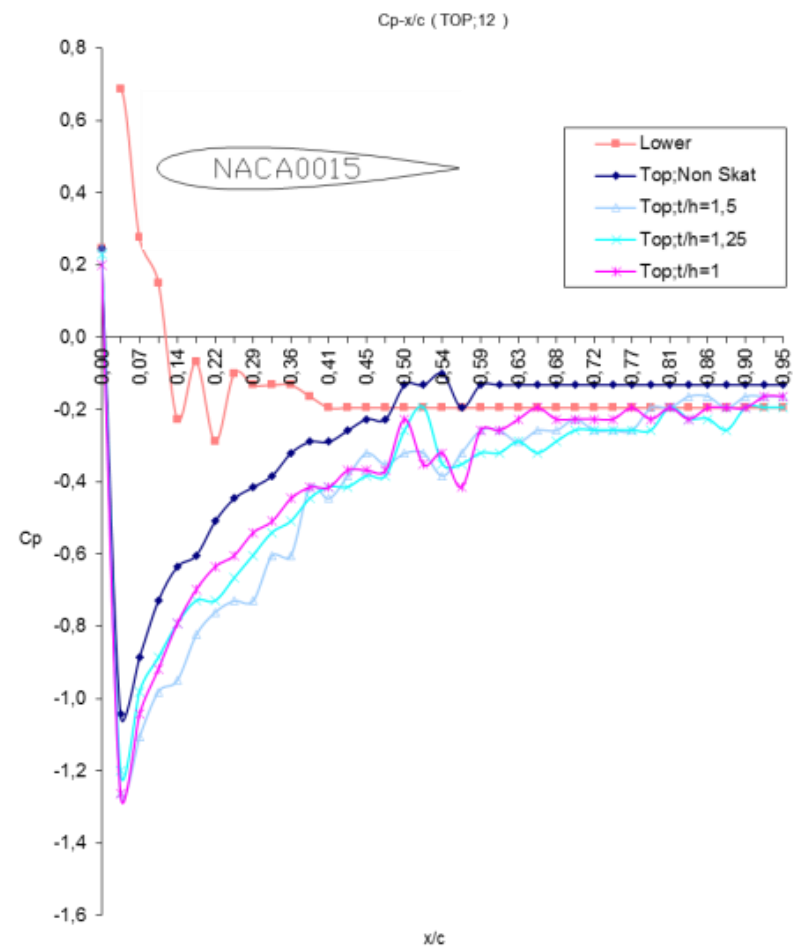

Gambar 8. Perubahan nilai $C_{P}$ terhadap x/c $\left(\alpha=12^{0}\right)$

\section{Perubahan nilai $C_{P}$ pada $\alpha=14^{0}$}

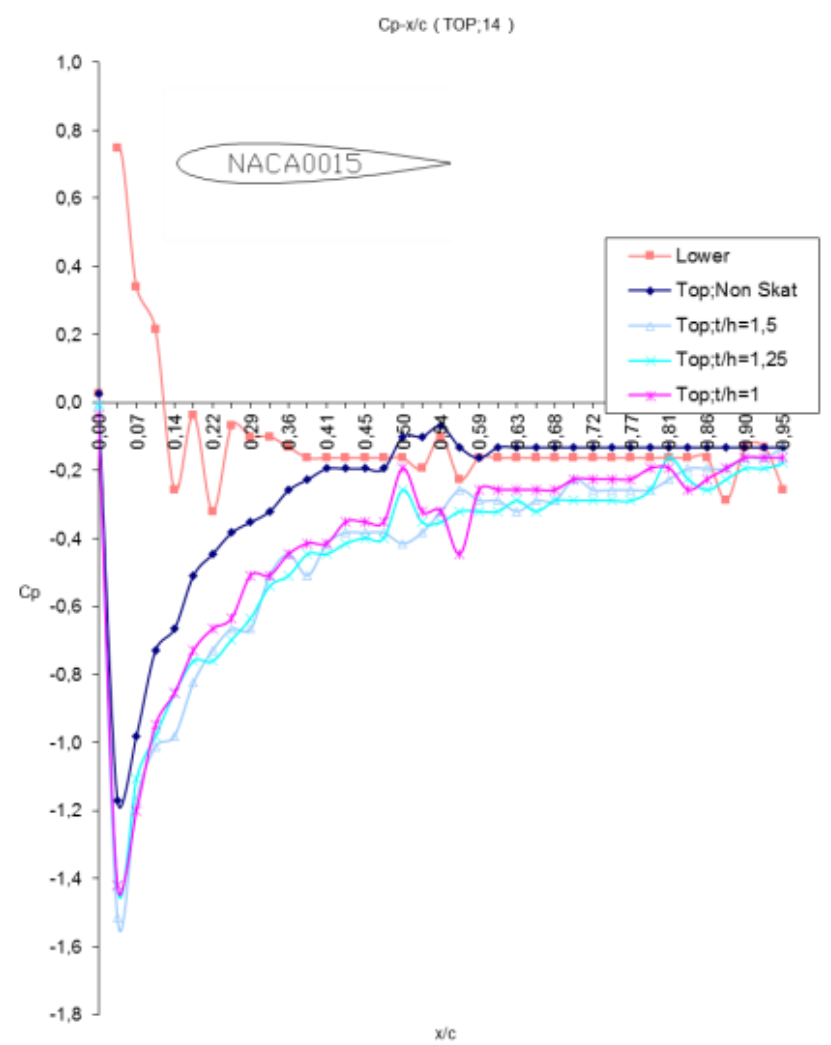

Gambar 9. Perubahan nilai $C_{P}$ terhadap x/c $\left(\alpha=14^{0}\right)$ 
Perubahan $C_{P}$ tanpa skat

Pada gambar 9 tampak sebelum menggunakan skat titik separasi terjadi di sekitar $43 \%$ Chord, pada permukaan atas sedangkan pada permukaan bawah aliran diperlambat pada awal masuk sisi bawah airfoil sehingga tekanannya naik dan disekitar 9\% chord aliran kembali dipercepat tetapi titik koeffisien tekanan minimum masih diatas koeffisien tekanan minimum sisi atas sehingga terjadilah perbedaan tekanan sisi atas dan sisi bawah yang bisa menghasilkan lift. Lift yang dihasilkan lebih besar dibandingkan sudut serang $0^{0}$ , $10^{\circ}$ dan $12^{0}$ hal ini dikarenakan titik koeffisien minimum sisi atas lebih ke bawah, yang berarti tekanan pada permukaan atas lebih kecil.

Pada permukaan bagian atas titik koeffisien tekanan minimum terjadi disekitar 9\% chord, Kemudian bergerak ke belakang aliran mengalami penurunan kecepatan. Tetapi aliran masih mampu mengatasi gaya gesek dari permukaan. Tetapi pada daerah sekitar 4.3\% Chord aliran mulai terseparasi dimana hal ini ditandai dengan Harga koeffisien tekanan yang cenderung mulai konstan. Hal ini berarti momentum yang ada sudah tidak mampu lagi mengatasi gaya gesek dan adverse pressure gradient yang semakin besar.

Perubahan $C_{P}$ dengan penambahan skat bagian atas

Dengan penambahan skat pada bagian atas ternyata membuat tekanan minimum di permukaan atas semakin turun kebawah. Sedangkan pada permukaan bawah relatif tidak berubah. Pada $\mathrm{t} / \mathrm{h}=1$ titik separasi terjadi agak mundur ke belakang dibanding dengan tanpa skat dan dengan tekanan yang lebih kecil.

Untuk $\mathrm{t} / \mathrm{h}=1,25$ titik koeffisien tekanan minimum lebih kebawah sehingga tekanan minimum yang dihasilkan lebih kecil dibanding dengan tanpa skat. Jika dibandingkan dengan $\mathrm{t} / \mathrm{h}=1$ tekanan minimumnya hampir sama tetapi pressure gradiennya lebih landai sehingga bisa dikatakan lebih sedikit kehilangan kecepatan yang disebabkan kontraksi aliran pada kondisi masukan antar skat dan gaya gesek pada dinding-dinding skat. Sedangkan pada permukaan bawah relatif tidak berubah. Pada $t / h=1,25$ titik separasi terjadi agak mundur ke belakang dibanding dengan tanpa skat selain itu dengan tekanan yang lebih kecil.

Untuk $\mathrm{t} / \mathrm{h}=1,5$ titik koeffisien tekanan minimum lebih kebawah lagi sehingga tekanan minimum yang dihasilkan lebih kecil dibanding dengan tanpa skat, $\mathrm{t} / \mathrm{h}=1$ dan $\mathrm{t} / \mathrm{h}=1,25$. Sedangkan pada permukaan bawah relatif tidak berubah. Pada $\mathrm{t} / \mathrm{h}=1,5$ titik separasi terjadi di daerah jarak chord yang lebih mundur dibanding dengan tanpa skat. Dari grafik diatas tampak dengan penambahan skat terjadi penurunan koeffisien tekanan minimum ini berarti ada akselerasi aliran sehingga momentum aliran yang menyebabkan perbedaan tekanan sisi atas dengan sisi bawah semakin besar sehingga lift yang dihasilkan semakin besar pula. Hal ini juga sebagai penunjang hasil pengukuran $C_{D}$ dan $C_{L}$ 


\section{Perubahan nilai $C_{P}$ pada $\alpha=16^{0}$}

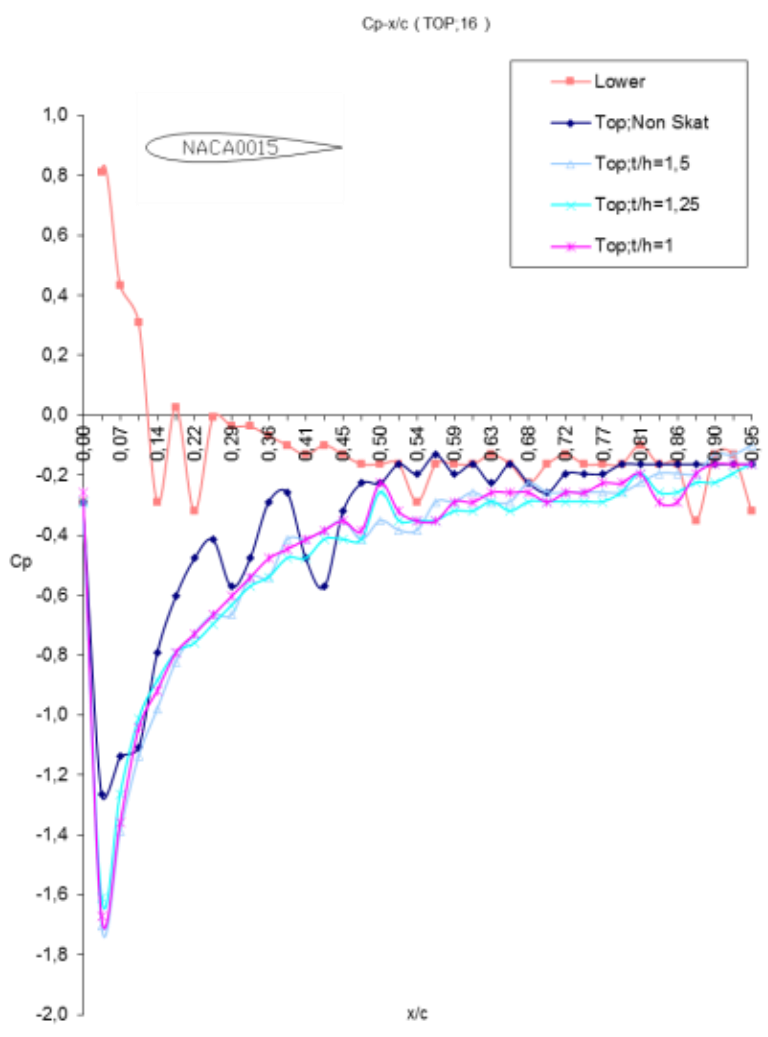

Gambar 10. Perubahan nilai $C_{P}$ terhadap x/c $\left(\alpha=16^{0}\right)$

\section{Perubahan $C_{P}$ tanpa skat}

Pada gambar tampak pada permukaan atas sebelum menggunakan skat pada awal sisi atas airfoil aliran mulai tidak teratur, Hal ini mungkin disebabkan adanya vortek yang timbul karena aliran tidak mampu melawan skin friction dan kontur airfoil dengan sudut serang yang terlalu besar. Sedangkan pada permukaan bawah aliran diperlambat pada awal masuk sisi bawah airfoil sehingga tekanannya naik dan disekitar 9\% chord aliran kembali dipercepat tetapi titik koeffisien tekanan minimum masih diatas koeffisien tekanan minimum sisi atas sehingga terjadilah perbedaan tekanan sisi atas dan sisi bawah yang bisa menghasilkan lift walaupun tidak bisa maksimum. Lift yang dihasilkan lebih besar dibandingkan sudut serang $0^{\circ}, 10^{\circ}$ dan $12^{\circ}$ tetapi lebih kecil dari $14^{0}$.

Perubahan $C_{P}$ dengan penambahan skat bagian atas

Dari grafik terlihat bahwa distribusi $C_{P}$ sepanjang cord lebih teratur, ini membuktikan bahwa Dengan penambahan skat pada bagian atas ternyata selain membuat tekanan minimum di permukaan atas semakin turun kebawah juga dapat mencegah vortek pada awal sisi atas airfoil, sehingga lift maksimum yang dihasilkan lebih besar.

Dari ketiga variasi jarak skat tampak distribusi harga $C_{P}$ hampir saling berimpit, baik koeffisien tekanan minimum maupun titik separasi. Sehingga kenaikan lift dari ketiga variasi jarak skat tidak jauh berbeda.

\section{SIMPULAN}

Dari analisa aliran fluida pada profil NACA0015 berskat bagian atas dengan variasi perbandingan jarak skat dengan tinggi skat, maka dapat disimpulkan:

1. Penambahan skat pada sisi atas dapat memberikan akselerasi aliran sehingga lebih mampu melawan gaya gesek dan adverse pressure gradient. Dengan demikian distribusi tekanan sepanjang chord lebih teratur dan terjadi peningkatan lift. 
2. Penambahan skat pada sisi atas profil NACA0015 dengan Reynolds number $2,27.10^{6}$ dan perbandingan jarak antar skat terhadap tinggi skat $(\mathrm{t} / \mathrm{h}) 1,5 ; 1,25 ; 1$, terbukti dapat meningkatkan lift tetapi peningkatan lift tersebut diikuti pula dengan peningkatan drag.

3. Besarnya peningkatan lift dan drag yang dihasilkan tergantung dari perbandingan antara jarak skat dengan tinggi skat $(\mathrm{t} / \mathrm{h})$. Pada $\mathrm{t} / \mathrm{h}$ yang terlalu kecil lift yang dihasilkan kecil dan drag yang dihasilkan besar.

4. Penambahan skat pada sisi atas airfoil NACA0015 dengan Reynolds number $2,27.10^{6}$ dan perbandingan jarak antar skat terhadap tinggi skat $(\mathrm{t} / \mathrm{h}) 1,5 ; 1,25 ; 1$, terbukti dapat meningkatkan kinerja sayap $\left(C_{L} / C_{D}\right)$.

5. Penambahan skat pada sisi atas airfoil NACA0015 dengan Reynolds number $2,27.10^{6}$ dan perbandingan jarak antar skat terhadap tinggi skat $(\mathrm{t} / \mathrm{h}) 1,5 ; 1,25 ; 1$, juga terbukti membuat stall terjadi terjadi pada sudut serang yang lebih besar (diatas $14^{\circ}$ ).

Dari kesimpulan diatas dapat dikatakan aliran fluida yang memasuki lorong-lorong skat diindikasikan dipengaruhi oleh aliran yang terkontraksi yang disebabkan oleh gaya gesek di permukaan diding skat. Disinilah fenomena aliran tiga dimensi terjadi pada kasus diatas.

\section{DAFTAR PUSTAKA}

Clancy, L. J, “Aerodynamics”, Pitman Publishing, London, 1978.

Schlichting and Truckenbrodt, "Aerodynamics of the Airplane ", McGrow-Hill Book Company, New York, 1979.

Fox, Robert W., Mc Donald, Alan T, "Introduction to Fuid Mechanic", 4 ${ }^{\text {th }}$ edition, John Willey and Sons, Inc, 1994.

Anderson, John D., Jr, “Fundamental of Aerodynamics”, $2^{\text {nd }}$ edition, Mc Grow-Hill Book Company, New York, 1985.

Schlichting, H, “Boundary Layer Theory”, $4^{\text {th }}$ edition, Mc Grow-Hill Book Company, New York, 1979.

Thwaites, B., "Approximate Calculations of The Laminar Boundary Layer", Aero. Quart, Vol. 1. 1949

Head, M. R. and Patel, V. C., "Improved Entrainment Method for Calculation Turbulent Boundary Layer Development”, ARC RM 3643., 1969

Abbott, Ira H. and Von Doenhoff, Albert E.,'Theory of Wing Sections", Dover Publications, Inc, New York., 1956

Kuethe, Arnold M. and Chow, Chuen-Yen, "Foundations of Aerodynamics", $4^{\text {th }}$ edition, John Wiley \& Sons, Canada, 1986. 